\title{
Pengukuran Radiasi Elektromagnetik Telepon Seluler Berdasarkan Tipe Telepon
}

\author{
Alun Pratama ${ }^{1 *}$, Jumingin, M. Si ${ }^{1}$, Atina, M. $\mathrm{Si}^{1}$ \\ ${ }^{1}$ Program Studi Fisika Fisika, Fakultas Sains dan Teknologi Universitas PGRI Palembang, \\ Palembang 30251, Indonesia \\ *e-mail:jumingin@univpgri-palembang.ac.id
}

Received: 0812 2021. Accepted: 1112 2021. Published: 122021

\begin{abstract}
Abstrak
Penelitian dilakukan pada juni 2021 menggunakan detector radiasi elektromagnetik di Universitas PGRI Palembang. Tujuan dari penelitian ini adalah untuk mengukur radiasi elektromagnetik yang dihasilkan oleh telepon seluler (ponsel) berdasarkan medan listrik dan medan magnet pada mode "on" dan mode "off" (standby). Metode penelitian yaitu dengan purposive sampling untuk mengetahui nilai rata-rata medan listrik dan medan magnet pada 10 tipe ponsel. Medan listrik tertinggi yaitu pada tipe 7, saat mode "on" yaitu is $306 \mathrm{~V} / \mathrm{m}$ dan pada mode "off" $267 \mathrm{~V} / \mathrm{m}$. Medan magnet tertinggi pada mode "on" 0,56 $\mu \mathrm{T}$ (tipe 7) and mode "off" $0,12 \mu \mathrm{T}$ (tipe 8). Medan listrik terendah pada mode "on" $12 \mathrm{~V} / \mathrm{m}$ (tipe 2), pada mode off 12 $\mathrm{V} / \mathrm{m}$ (tipe 2 and 4). Medan magnet terendah adalah $0 \mu \mathrm{T}$ pada tipe 3, 5 dan 6 saat mode "on" dan mode "off" pada 8 tipe ponsel. Hasil penelitian menunjukkan bahwa medan listrik dan medan magnet yang terukur berada dibawah ambang batas yang ditetapkan WHO.
\end{abstract}

Kata Kunci: Telepon Seluler, Medan Listrik, Medan Magnet, Mode On dan Mode Off

\section{Cellphone Elektromagnetic Radiation Measurement by Phone Type}

\begin{abstract}
This research has been done on June using electromagnetic radiation detector in University of PGRI Palembang. The purpose of this research was to find out the electromagnetic radiation generated by cell phone based on electric and magnetic field at "on" and "off" mode (standby). The method that has been used is purposive sampling to get the average electric and magnetic field value on 10 types of cell phone. The highest electric field value is on the cell phone type 7, in the "on" mode is $306 \mathrm{~V} / \mathrm{m}$ and in the "off" mode is 267 $\mathrm{V} / \mathrm{m}$. The highest magnetic field value in the "on" mode is 0,56 $\mu$ T (type 7), in the "off" mode is $0,12 \mu T$ (type 8). The lowest electric field value in the "on" mode is $12 \mathrm{~V} / \mathrm{m}$ (type 2), in the "off" mode is $12 \mathrm{~V} / \mathrm{m}$ (type 2 and 4). The lowest magnetic field value in the "on" mode is $0 \mu T$ (type 3, 5 and 6), in the "off" mode is $0 \mu$ T for 8 types cell phone. The result of this study show that the measured electric and magnetic field value are below the threshold set by WHO.
\end{abstract}

Keywords: Cellphone, electrikc field, magnetic field, on mode and off mode

\section{PENDAHULUAN}

Kemajuan era yang sangat pesat menyebabkan manusia sangat tergantung pada teknologi mutahir semacam telepon seluler, dengan mengoperasikan suatu ponsel manusia bisa melaksanakan bermacam perihal tanpa melaksanakannya sendiri, dalam dunia kerja ataupun kebutuhan tiap hari. Pemakaian ponsel pada warga telah jadi kebutuhan primer semacam santapan serta minuman, tetapi tanpa disadari bisa membahayakan kesehatan yang disebabkan oleh dampak radiasi dari telepon seluler( Hartina et.al., 2014).

Hardell (2007) dan Salford et.al. (2006) menuturkan bahwasannya radiasi 
mempunyai suatu pemancaran ataupun penyinaran. Radiasi ialah penyebaran partikel-partikel elementer serta energi radiasi dari suatu sumber radiasi ke medium ataupun tujuan sekitarnya. Intensitas radiasi yang dipancarkan oleh ponsel ialah gelombang elektromagnetik yang bersifat bisa menembus ruang hampa udara. Radiasi yang diakibatkan oleh ponsel dapat berdampak buruk bagi manusia, secara komulatif radiasi ponsel memunculkan bermacam-macam penyakit seperti tumor otak, alzheimer, fatigue, kanker otak, dan yang paling ringan adalah sakit kepala.

Berdasarkan hasil pengukuran penelitian intensitas radiasi gelombang elektromagnetik nilai kuat medan listrik dan kuat medan magnet menunjukkan bahwa masih menunjukkan dibawah ambang batas yang ditetapkan oleh WHO. Badan Kesehatan Wolrd Health Organization merekomendasikan bahwa nilai ambang batas paparan kuat medan listrik dan kuat medan magnet $50 / 60 \mathrm{~Hz}$ untuk kelompok umum adalah $5 \mathrm{kV} / \mathrm{m}$ dan $100 \mu \mathrm{T}$, untuk kelompok pekerja $10 \mathrm{kV} / \mathrm{m}$ dan $500 \mu \mathrm{T}$ (Tribuana, 2000).

Menurut Syahria et.al. (2012) radiasi ialah pemancaran energi yang berbentuk gelombang atau partikel yang dipancarkan oleh sumber atau zat radioaktif. Radiasi elektromagnetik merupakan suatu kombinasi medan listrik dan medan magnet yang berosilasi serta merambat melalui ruang dan membawa energi dari satu tempat ke tempat lainnya. Cahaya tampak ialah salah satu bentuk radiasi elektromagnetik (Wijaya et.al., 2009).

Gelombang elektromagnetik ialah gelombang yang terbentuk jika ada suatu usikan/gangguan dari medan listrik dan medan magnetik yang bergetar saling tegak lurus, keadaan sperti inilah merupakan terjadinya gelombang tranversal dengan arah rambatannya tegak lurus dengan arah getarnya (Mahardika, 2009).
Tujuan penelitian ini adalah untuk menganalisis intensitas radiasi elektromagnetik berupa nilai kuat medan listrik dan kuat medan magnet yang dihasilkan oleh setiap tipe ponsel pada saat mode on (pada saat ponsel sedang digunakan dalam hal ini ketika saat ponsel dalam mode panggilan seluler) dan mode off (ketika ponsel dalam keadaan tidak digunakan (standby)).

Berdasarkan penjelasan diatas maka batasan masalah pada penelitian ini yaitu intensitas radiasi elektromagnetik yang diukur berupa kuat medan listrik dan kuat medan magnet.

\section{BAHAN DAN METODE}

Adapun alat yang digunakan dalam penelitian ini diantaranya :

1. Elektroamgnetic radiation detector

2. Telepon seluler

3. Stopwach

Prosedur dalam penelitian ini yaitu :

1. Persiapan alat elektromagnetic radiation detector,

2. Pastikan alat dalam keadaan baik/dikalibrasi

3. Letakkan alat ukur di depan monitor ponsel

4. Ukur intensitas radiasi gelombang elektromagnetik dari ponsel (kuat medan listrik dan kuat medan magnet) pada saat mode on dan mode off menggunakan alat ukur elektromagnetic radiation tester

5. Pengukuran medan listrik dan medan magnet dilakukan setelah 5 detik dioperasikan electromagnetic radiation tester

6. Ulangi langkah $\mathrm{a}, \mathrm{b}$ dan $\mathrm{c}$ untuk tipe ponsel yang lainnya.

Penelitian ini menggunakan metode Purpossive Sampling yaitu dengan menentukan tipe ponsel yang akan diukur intensitas radiasi elektromagnetiknya. Dalam pengambilan data ini dilakukan pengukuran di Fakultas Sains dan 
Tekonologi Universitas PGRI Palembang, dalam hal ini pengukuran dilakukan untuk mengetahui intensitas kuat medan listrik dan kuat medan magnet dalam mode on dan mode off yang dihasilkan oleh 10 tipe ponsel yang berbeda dengan menggunakan alat elektromagnetic radiation detector.

\section{HASIL DAN PEMBAHASAN}

Berdasarkan hasil Pengukuran intensitas radiasi elektromagnetik yang dipancarkan oleh ponsel dengan mode on dan off. Pengukuran dilakukan pada 15 ponsel yang berbeda dengan perlakuan yang sama dan nilai intensitas dibaca tepat pada detik ke-5 setelah alat menerima pancaran radiasi elektromagnetik dari ponsel. Hasil pengukuran yang didapat dari pancaran radiasi elektromagnetik ponsel berupa nilai kuat medan listrik dan kuat medan magnet.

Nilai kuat medan listrik dan kuat medan magnet yang didapat dapat dilihat pada tabel berikut :

Tabel 1. Hasil pengukuran Medan Listrik dan Medan Magnet

\begin{tabular}{cccccc}
\multirow{2}{*}{ No } & Tipe Ponsel & \multicolumn{2}{c}{ Kuat Medan Listrik (V/m) } & \multicolumn{2}{c}{ Kuat Medan Magnet $(\mu \mathrm{T})$} \\
& & Mode on & Mode off & Mode on & Mode off \\
\hline 1 & Ponsel Tipe 1 & 13 & 9 & 0,37 & 0 \\
2 & Ponsel Tipe 2 & 12 & 5 & 0,31 & 0 \\
3 & Ponsel Tipe 3 & 113 & 46 & 0 & 0 \\
4 & Ponsel Tipe 4 & 94 & 5 & 0,11 & 0 \\
5 & Ponsel Tipe 5 & 143 & 77 & 0 & 0 \\
6 & Ponsel Tipe 6 & 214 & 167 & 0 & 0 \\
7 & Ponsel Tipe 7 & 306 & 267 & 0,56 & 0,11 \\
8 & Ponsel Tipe 8 & 153 & 120 & 0,4 & 0,12 \\
9 & Ponsel Tipe 9 & 20 & 13 & 0,5 & 0 \\
10 & Ponsel Tipe 10 & 87 & 50 & 0,31 & 0 \\
\hline
\end{tabular}

Dari Tabel 1. di atas hasil pengukuran diperoleh nilai tertinggi dari nilai kuat medan listrik pada mode on yaitu pada ponsel dengan tipe 7 yaitu 306 $\mathrm{V} / \mathrm{m}$ dan pada mode off yaitu pada ponsel dengan tipe 7 yaitu $267 \mathrm{~V} / \mathrm{m}$. Sedangkan nilai kuat medan magnet yang tertinggi pada mode On oleh ponsel tipe 7 yaitu $0,56 \mu \mathrm{T}$ dan pada mode Off oleh ponsel tipe 8 yaitu $0,12 \mu \mathrm{T}$. Nilai kuat medan listrik terendah pada mode On yaitu pada ponsel dengan tipe 2 yaitu $12 \mathrm{~V} / \mathrm{m}$, sedangkan pada mode Off terdapat 2 tipe ponsel dengan nilai yang sama pada tipe 2 dan ponsel tipe 4 yaitu $5 \mathrm{~V} / \mathrm{m}$. Nilai kuat medan magnet yang terendah pada mode On terdapat 3 tipe ponsel dengan nilai yang sama pada tipe 3 , tipe 5 dan tipe 6 yaitu $0 \mu \mathrm{T}$, dan pada mode Off terdapat bahwa 8 tipe ponsel dengan nilai yang sama pada tipe 1 , tipe 2 , tipe 3 , tipe 4 , tipe 5 , tipe 6 , tipe 9 dan tipe 10 yaitu 0 $\mu \mathrm{T}$.

Dalam hal ini faktor yang mempengaruhi adanya medan listrik timbul dikarenakan komponenkomponen pada ponsel terdapat muatan listrik yang disebabkan oleh motor listrik pada ponsel sebagai mesin pengoperasiannya (Athena et.al., 1999/2000). Disaat yang sama medan magnetik akan terbentuk dengan menggerakkan muatan listrik (arus listrik). Medan listrik dan medan magnet timbul dimanapun ketika adanya arus listrik mengalir (WHO, 2007).

Pada penelitian ini, pengukuran dilakukan pada 10 tipe ponsel dengan 
tipeyang berbeda-beda. Hasil pengukuran kuat medan listrik dan medan magnet hasil pegukuran nilai kuat medan listrik dan kuat medan magnet dapat dilihat pada tabel 1 sebagai berikut:

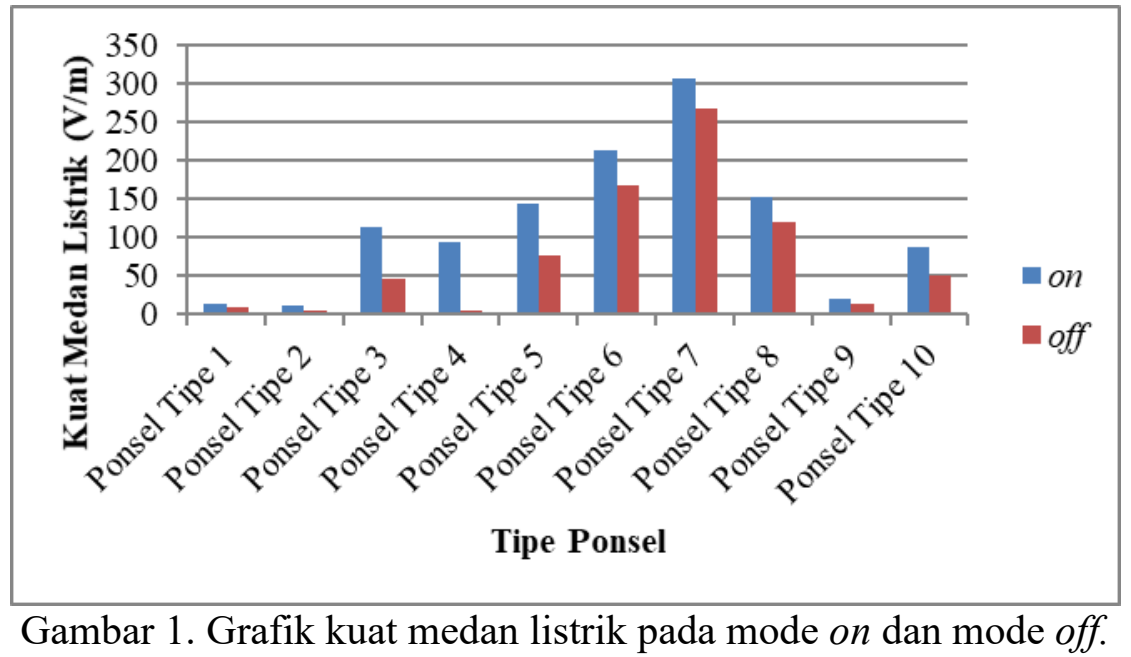

Gambar 1. terlihat bahwa pengukuran diperoleh nilai tertinggi dari nilai kuat medan listrik pada mode on yaitu pada ponsel dengan tipe 7 yaitu 306 $\mathrm{V} / \mathrm{m}$ dan pada mode off yaitu pada ponsel dengan tipe 7 yaitu $267 \mathrm{~V} / \mathrm{m}$. Sedangkan nilai kuat medan listrik terendah pada mode On yaitu pada ponsel dengan tipe 2 yaitu $12 \mathrm{~V} / \mathrm{m}$, sedangkan pada mode Off terdapat 2 tipe ponsel dengan nilai yang sama pada tipe 2 dan ponsel tipe 4 yaitu $5 \mathrm{~V} / \mathrm{m}$.

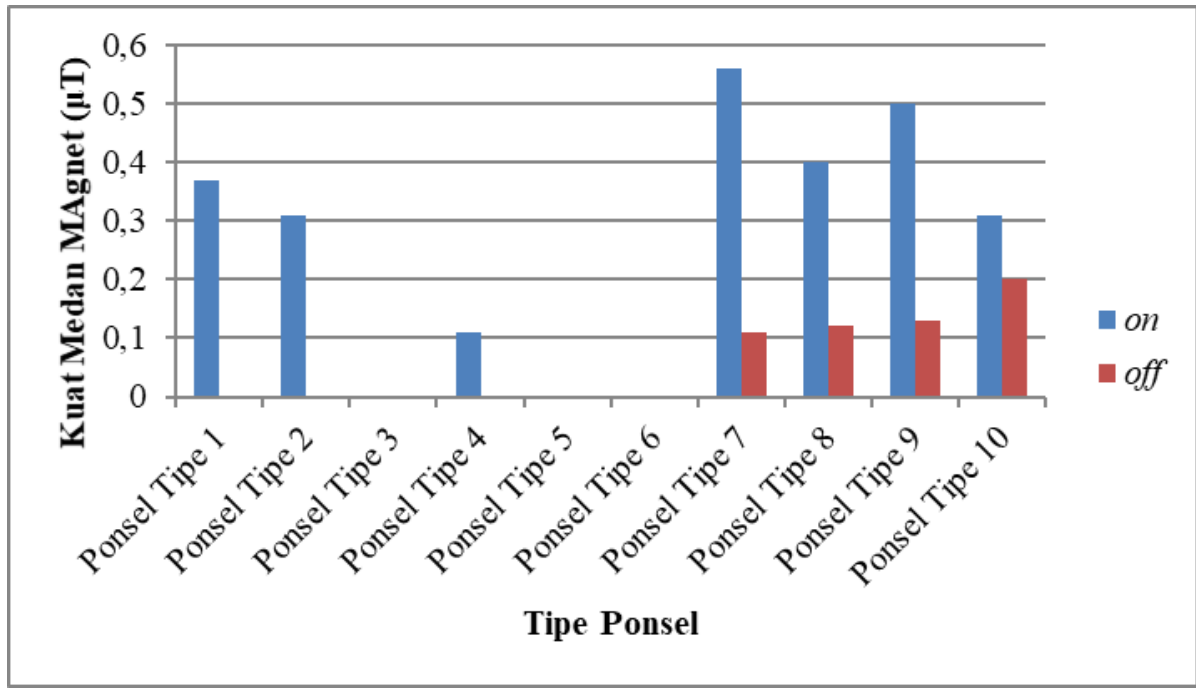

Gambar 2. Grafik kuat medan magnet pada mode on dan mode off.

Pada Gambar 2. terlihat bahwa kuat medan magnet pada mode on dengan nilai tertinggi timbul pada ponsel tipe 7 . Pada mode off ditunjukkan pada ponsel 8 yaitu $0,12 \mu \mathrm{T}$. Sedangkan nilai terendah kuat medan magnet terendah pada mode On terdapat 3 tipe ponsel dengan nilai yang sama pada tipe 3 , tipe 5 dan tipe 6 yaitu $0 \mu \mathrm{T}$, dan pada mode Off terdapat bahwa 8 tipe ponsel dengan nilai yang sama pada tipe 1 , tipe 2 , tipe 3 , tipe 4 , tipe 5 , tipe 6 , tipe 9 dan tipe 10 yaitu 0 $\mu \mathrm{T}$.

Berdasarkan hasil pengukuran penelitian intensitas radiasi gelombang elektromagnetik berdasarkan kuat medan listrik dan kuat medan magnet menunjukkan bahwa masih menunjukkan 
dibawah ambang batas yang ditetapkan oleh WHO. Badan Kesehatan Wolrd Health Organization merekomendasikan bahwa nilai ambang batas paparan kuat medan listrik dan kuat medan magnet $50 / 60 \mathrm{~Hz}$ untuk kelompok umum adalah $5 \mathrm{kV} / \mathrm{m}$ dan $100 \mu \mathrm{T}$, untuk kelompok pekerja $10 \mathrm{kV} / \mathrm{m}$ dan $500 \mu \mathrm{T}$ (Tribuana, 2000).

Pada penelitian ini kuat medan listrik dan kuat medan magnet dari semua tipe yang telah diukur menunjukkan bahwa masih dalam ambang batas aman yang ditentukan WHO, yaitu pada kuat medan listrik sebesar $306 \mathrm{~V} / \mathrm{m}$ dan medan magnet sebesar $0,56 \mu \mathrm{T}$.

Dari hasil penelitian ini dapat disimpulkan pada mode $O n$ (dalam panggilan) memiliki nilai yang lebih tinggi dibandingkan dengan mode $O f f$ (stand by). Namun besar medan magnet yang dihasilkan oleh ponsel masih dibawah ambang batas yang ditetapkan oleh WHO akan tetapi dalam pengoperasian ponsel secara terus menerus tetap akan menimbulkan dampak negatif terhadap kesehatan tubuh.

\section{KESIMPULAN}

Berdasarkan hasil dan pembahasan pada penelitian ini dapat disimpulkan bahwa kuat medan listrik tertinggi ditimbulkan oleh ponsel tipe 7 yaitu 306 $\mathrm{V} / \mathrm{m}$ sedangkan nilai terendahnya ditimbulkan oleh ponsel tipe 2 dan tipe 4 dengan nilai yang sama yaitu $5 \mathrm{~V} / \mathrm{m}$. Kuat medan magnet tertinggi ditimbulkan oleh ponsel tipe 7 yaitu 0,56 $\mu \mathrm{T}$ sedangkan nilai terendahnya ditimbulkan oleh ponsel tipe 1, tipe, tipe 2 , tipe 3 , tipe 4 , tipe 5 , tipe 6 , tipe 9 dan tipe 10 dengan nilai yang sama yaitu 0 $\mu \mathrm{T}$. Berdasarkan data pada penelitian bahwa nilai kuat medan listrik dan kuat medan magnet masih dibawah ambang batas aman yang ditentukan oleh WHO.

\section{DAFTAR PUSTAKA}

Athena, T. Tugaswati dan Sukar. 1999/2000 Kuat Medan Listrik Dan Medan Magnet Pada Peralatan Rumah Tangga Dan Kantor, 27 (1).

Hardell, L. 2007. Research Report, Örebro University in Sweden. Di akses pada 27 Maret 2021.

Hartina, Iswandi, dan L. M. Said. 2014. Pengukuran Intensitas Radiasi yang Dipancarkan oleh Ponsel dan Pengaruhnya Terhadap Kesehatan. Jurnal Teknosain, 8 (1): 109-120.

Mahardika, I.P. 2009. Efek Radiasi Elektromagnetik Ponsel Terhadap Kesehatan Manusia. Jurnal Elektro Indonesia.

Salford, Brun, Persson, Eberhardt, dan Malmgren. 2006. Studied the effects of microwave radiation on the rat brain. Swedish Researchers, Lund University.

Syahria, E. Setiawati, dan K. S. Firdausi. 2012. Pembuatan Kurva Isodosis Paparan Radiasi di Ruang Pemerikasaan Instalasi Radiologi RSUD Kabupaten Kolaka Sulawesi Tenggara. Jurnal Berkala Fisika, 15(4): 123-132.

Tribuana, N. 2000. Pengukuran Medan Listrik dan Medan Magnet di bawah SUTET 500kV. Widyaiswara Batan patn-Batan Elektro Indonesia, VI (32).

Wijaya, N. H., W. Kartika, dan A. R. D. Utari. 2019. Deteksi Radiasi Gelombang Elektromagnetik Dari Peralatan Medis dan Elektronik di Rumah Sakit. Jurnal ECOTIPE, 6(2): 102-106.

Word Health Organization. 2007. Electromagnetic Field and Public Health. 